\title{
Determination of Drying Characteristics, Energy Consumption and Quality Values of Black Mulberry Fruit (Morus nigra L.) Dried Under Different Conditions
}

\author{
Muhammed Taşova ${ }^{1, a, *}$, Hakan Polatcı ${ }^{1, b}$, Adil Koray Yıldız ${ }^{2, c}$ \\ ${ }^{1}$ Biosystem Engineering Department, Faculty of Agriculture, Tokat Gaziosmanpaşa University, 60250 Tokat, Turkey \\ ${ }^{2}$ Biosystem Engineering Department, Faculty of Engineering and Architecture, Yozgat Bozok University, 66200 Yozgat, Turkey \\ ${ }^{*}$ Corresponding author \\ A R T I C L E I N F O \\ A B S T R A C T \\ Research Article \\ Received : 06/01/2020 \\ Accepted : 14/02/2021 \\ Keywords: \\ Drying \\ Dry duration \\ Modelling \\ Specific energy consumption \\ Quality analysis \\ There are about 68 types of mulberry fruit with a wide ecological production area. Different \\ mulberry species are grown in large fields in Turkey. Mulberries are largely dried-consumed, but \\ sometimes they are used as fruit juice. In this study, black mulberry fruit was collected in two \\ different ripening levels (semi-ripe and full-ripe) and oven-dried at 50, 60 and $70^{\circ} \mathrm{C} \mathrm{drying}$ \\ temperatures. Initial moisture contents of semi-ripe and full-ripe fruits were determined as $86.74 \%$ \\ and $82.95 \%$, respectively. Fruits were dried to have final moisture levels of 10-15\%. Drying \\ duration, drying models, effective diffusion, activation energy, specific energy consumption, color \\ parameters and chemical properties of dried fruits were examined and the effect of ripening levels \\ and drying temperatures were investigated. In terms of drying duration, while full-ripe fruits dried \\ in a shorter time, effective diffusion, activation energy and specific energy consumption values \\ were found to be higher than semi-ripe fruits. In terms of color parameters, semi-ripe fruits are \\ recommended to be dried at 50 or $60^{\circ} \mathrm{C}$ drying temperatures and full-ripe fruits should be dried at \\ $50^{\circ} \mathrm{C}$ drying temperature for better preservation of color parameters. On the other hand, a common \\ proper drying temperature could not be identified for acidity $(\mathrm{pH})$, water soluble dry matter and \\ titratable acidity.
}

\section{Introduction}

Fruits are easily perished after the harvest because of high moisture contents. Therefore, for long-term preservations without any deterioration, fruits are either subjected to drying processes or cold storage operations (Doymaz, 2011; Ghanbarian et al., 2019). Initial investment costs and energy consumption values of cold storage operations are greater than the drying processes, thus cold storage could not be used by every growers. Tellez et al. (2019) indicated the primary target of the drying process as to reduce water activity through removing a majority of product moisture and thus to reduce microbic formations. Besides, drying significantly reduces fruit weight and volumes, thus facilitate loading-unloading and transportation operations. Drying also offers alternative products with high market values.

Producers generally dry their products in trays or layout over concrete surfaces under direct sunlight (open drying) (Wojdylo et al., 2014; Panagopoulou et al., 2019). In opendrying methods (sun-shade), process durations are too long, it is hard to control drying temperature and it is generally impossible to prevent dust, odor, etc. coming from the environment, thus it is most of the time hard to get quality and hygienic final products (Doymaz et al., 2003; Özgen, 2014; Polatc1 et al., 2018). Then, to eliminate such negative issues or conditions, conventional drying methods, in which drying is conducted in closed ambient and product specific drying conditions are controlled, were developed. Among these methods, oven-drying offers various advantages, significantly reduces drying durations and yields quality final products (Figiel, 2010). Black mulberry fruit is largely used in jam, smoothie, pancake, sweet and sauces. In terms of human health, black mulberry fruit is rich in vitamins, minerals and carbohydrates supplying energy to the cells through converting sugar into glucose. Mulberry also increases iron uptake of the body and supplies sufficient oxygen to tissues. Black mulberry is among the commonly dried fruits.

There are some studies available in the literature about mulberry drying. Ergüneş et al. (2003) investigated the effects of different drying techniques on the quality of dried mulberry samples and reported that conventional 
driers yielded greater darkened color parameters as compared to sun-dried samples. Chen et al. (2017) investigated the effects of combined hot air drying and explosion puff drying and freeze drying and puff drying on physicochemical characteristics of mulberry samples. Researchers reported that the best anthocyanin conservation was achieved with freeze drying and a combination of freeze drying and explosion puff drying yielded the best outcomes in terms of color conservation, taste and texture. In the same study, drying durations were also compared and optimum drying duration for final moisture of $7 \%$ was reported as 9 hours for hot air drying, 6 hours for hot air and explosion puff drying, 48 hours for freeze drying and 15 hours for freeze drying and explosion puff drying. Dobooğlu (2012) dried black mulberry samples with the use of lyophilization, conventional and vacuum drying methods and analyzed anthocyanin content, moisture content, rehydration capacity and color parameters. It was reported that as compared to conventional drying, vacuum drying offered better preservation of investigated parameters; the samples dried with conventional and vacuum drying methods had denser anthocyanin and volatile compounds, thus greater values for these parameters when they were subjected to high temperature, then had darker colors than the samples dried with fresh and lyophilization methods; besides, these samples had lower L and a values; samples drier with lyophilization method had lower losses in anthocyanin content and greater rehydration capacity than the samples dried with the other drying methods; the lowest bulk density, water activity and moisture contents were observed in lyophilization method; because of low heat treatment, low level of loss was observed in $\mathrm{L}$ and a values, thus dried products had greater color quality. Despite the aforementioned studies, the number of studies about the effects of ripening stages and drying temperatures on drying kinetics and quality indicators of black mulberry is quite limited.

In this study, black mulberry fruit was dried in an oven at 50,60 and $70^{\circ} \mathrm{C}$ temperatures and the effects of ripening levels and drying temperatures on drying duration, drying model, specific energy consumption, effective diffusion, activation energy, color, acidity $(\mathrm{pH})$, water soluble dry matter (WSDM) and titratable acidity (TA) of black mulberry fruit were investigated.

\section{Material and Method}

\section{Fruits to be Dried and Ripening Levels}

Semi and full-ripe black mulberry fruits to be used as the drying material were collected from a grower orchard in Kemalpaşa village of Tokat province on 14th of July, 2020. Fresh samples were brought to drying laboratory of Biosystems Engineering Department of Tokat Gaziosmanpaşa University and preserved at $+4 \pm 0.5^{\circ} \mathrm{C}$ temperature. Bruised fruits were removed from the samples (Figure 1). Fruits were kept in a fridge until the end of drying process.

To separate fruits into two different ripening levels, color brightness (L) was measured with a color meter and fruits were classified into ripening levels as; Semi-ripe for L values of between 29.44-40.26 and full-ripe for $L$ values of between 18.33-29.44.

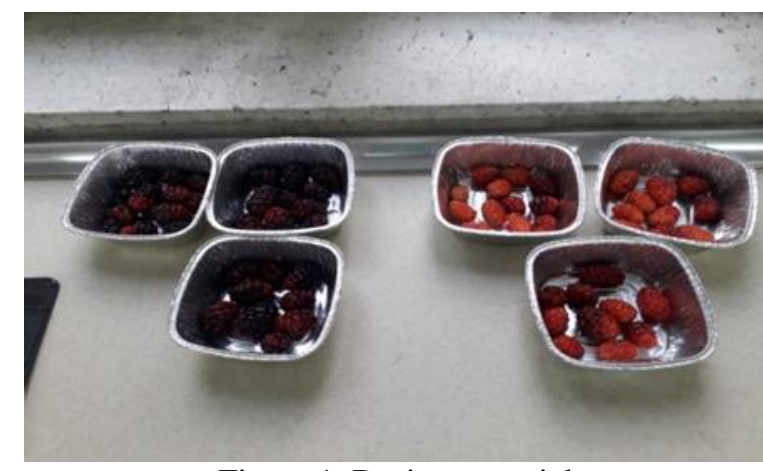

Figure 1. Drying material

\section{Moisture Content (\%) and Drying Temperature}

Before the drying process of black mulberry samples separated into two different ripening levels, wet-basis initial moisture content $(\%)$ was determined. For moisture content analysis, about $30.41 \pm 0.69 \mathrm{~g}$ and $39.87 \pm 0.52 \mathrm{~g}$ samples were taken from semi-ripe and full-ripe black mulberry fruits, respectively and samples were dried in an oven at $70^{\circ} \mathrm{C}$ until a constant mass (Pixton and Warburton, 1973). For drying process, $47 \pm 2.38 \mathrm{~g}$ and $34 \pm 1.28 \mathrm{~g}$ samples were taken from semi-ripe and full-ripe black mulberry fruits, respectively and samples were dried in an oven at 50,60 and $70^{\circ} \mathrm{C}$ temperatures in 3 replicates. Samples were dried until final moisture levels of $10-15 \%$ (Polatc1 and Tarhan, 2009). During the drying process, sample weight changes were monitored with the use of precise balance $( \pm 0.01 \mathrm{~g})$ (AND brand GF-3000 model). Şimşek Laborteknik brand ST-120 type oven was used in drying experiments and drying air temperature was adjusted with a PID controller installed on the device.

\section{Drying Model}

The moisture removed (MR) throughout the drying process of semi-ripe and full-ripe black mulberry fruits were calculated with the use of Equation 1, then thin-layer mathematical drying models were generated.

$$
\mathrm{MR}=\frac{\mathrm{M}-\mathrm{M}_{\mathrm{e}}}{\mathrm{M}_{0}-\mathrm{M}_{\mathrm{e}}}
$$

Where;

MR : Moisture ratio

M : Actual moisture

$\mathrm{M}_{\mathrm{e}}$ : Equilibrium moisture

$\mathrm{M}_{\mathrm{o}}$ : Initial moisture

The thin-layer drying models used to model drying ratios of the dried fruits mathematically are provided in Table 1.

While modeling drying ratios of the dried fruits, commonly used Midilli et al., Page and Yağcıoğlu models were selected.

\section{Effective Diffusion and Activation Energy}

Effective diffusion designates the time-dependent diffusion area of the moisture released from the fruits during the drying process. Effective diffusion values were calculated with the use of Equation 2 (Crank, 1979; Türker and İşleroğlu, 2017). 
$\ln \mathrm{MR}=\ln \frac{8}{\pi^{2}}-\frac{\pi^{2} \cdot \mathrm{D}_{\text {eff }} \cdot \mathrm{t}}{4 \mathrm{~L}^{2}}$

Where;

Deff : Effective diffusion $\left(\mathrm{m}^{2} \cdot \mathrm{s}^{-1}\right)$,

L : Product thickness (m).

Temperature-dependent change of resultant effective diffusion value was expressed with the use of Arhenius equation. Activation energy values were calculated with the use of Equation 3:

$$
\mathrm{D}_{\mathrm{eff}}=\mathrm{D}_{\mathrm{o}} \exp \left(-\frac{\mathrm{E}_{\mathrm{A}}}{\mathrm{RT}}\right)
$$

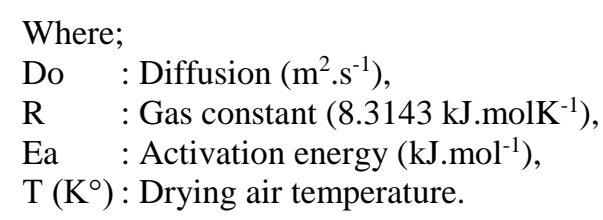

Activation energy (Ea) values were calculated from the slope of the line drawn with the use of natural logarithm of effective diffusion (Deff) coefficients versus 1/T values.

\section{Energy Consumption}

Energy consumption of drier is measured in $\mathrm{kWh}$ and final value was recorded when the desired product moisture content was achieved. Then, total energy consumption was used to calculate specific energy consumption values based on removed moisture quantities (Equation 5).

$$
\mathrm{SEC}=\frac{\mathrm{TEEC}}{\mathrm{TML}}
$$

Where;

SEC : Specific energy consumption $\left(\mathrm{kWh} . \mathrm{kg}\right.$ water $\left.{ }^{-1}\right)$, TEEC : Total electrical energy consumption (kWh), TML : Total moisture loss (kg).

\section{Color Measurements}

The $L^{*}, a^{*}$ and $b^{*}$ color parameters of fresh and semiripe and full-ripe dried fruits were measured with the use of a color meter (Minolta brand CR300 model).

$L *$ represents the brightness and gets values of between 0-100 with 0 indicating black fruit color and 100 indicating white fruit color. Color parameter of a represents red-green colors and $b^{*}$ represents yellow-blue colors. Negative $a^{*}$ values indicate more intense green color and positive a values indicate more intense red color. The $a^{*}$ and $b^{*}$ values equal to zero indicate grey color (McGuire, 1992). With the use of measured $L^{*}, a^{*}$ and $b^{*}$ values, chroma, hue angle and total color change reviling more distinctive color information was calculated.

Chroma indicates color tone of fresh and semi-ripe and full-ripe dried fruits. Pale colors have low and vivid colors have high chroma values. Hue angle designates the position of color on $360^{\circ}$ color radiant. The boundary values, $0^{\circ}$ represent red, $180^{\circ}$ green, $90^{\circ}$ yellow and $270^{\circ}$ blue colors. Total color change designates the color differentiation through heat-induced non-enzymatic reactions as compared to fresh color of the product.

The equations provided in Table 2 were used to calculate the chroma, hue angle and total color change parameters.

Where; $L^{*}, a^{*}$ and $b^{*}$ values represent the measured color values of fresh, semi-ripe and full-ripe black mulberry fruits; $L^{*}, a^{*}$ and $b^{*}$ values represent the measured color values of dried semi-ripe and full-ripe black mulberry fruits.

\section{Chemical Analyses}

Acidity (pH), water soluble dry matter (WSDM), titratable acidity (TA), total phenol (TP), total antioxidant capacity (TAC) and total anthocyanin content of semi-ripe and full-ripe fresh and dried products were determined (Figure 2).

Before the analyses, fresh and dried black mulberry fruits were diluted 4 and 9 times and extractions were performed in a blender.

Acidity: The $\mathrm{pH}$ values were measured in extracts of fresh and dry fruits with a $\mathrm{pH}$ meter.

Titratable acidity (\%): About $5 \mathrm{~mL}$ extracts of fresh and dried fruits were taken and titrated with $0.1 \mathrm{~N} \mathrm{NaOH}$ solution until a pH of 8.2. Titrations were conducted in 3 parallels and average was taken as titratable acidity (\%) of the samples.

Water soluble dry matter (WSDM) (\%): Fresh and dry fruit extracts were pressed to get juice and water-soluble dry matter contents were measured in a portable digital precise $( \pm 0.01)$ refractometer (Karaçalı, 1990; Cemeroğlu, 1992).

\section{Statistical Analysis}

Experimental data on semi-ripe and full-ripe fresh and dried samples were subjected to variance analysis with the use of SPSS 20 software and significant means were compared with the use of Duncan's multiple range test.

Table 1. Equations for drying models

\begin{tabular}{l|ll}
\hline \multicolumn{1}{c|}{ Model } & \multicolumn{1}{c}{ Equation } & \multicolumn{1}{c}{ Reference } \\
\hline Midilli et al. & $\mathrm{MR}=\mathrm{h} \cdot \exp \left(-\mathrm{j} \cdot \mathrm{t}^{\mathrm{k}}\right)+\mathrm{mt}$ & Midilli et al. (2002) \\
Page & $\mathrm{MR}=\exp \left(-\mathrm{kt} \mathrm{t}^{\mathrm{h}}\right)$ & Page (1949) \\
Yağcioğlu & $\mathrm{MR}=\mathrm{k} \cdot \exp (-\mathrm{h} \cdot \mathrm{t})+\mathrm{j}$ & Yağc1oğlu (1999) \\
\hline
\end{tabular}

\begin{tabular}{|c|c|c|}
\hline Color parameters & Equation & Reference \\
\hline Croma, C & $\mathrm{C}=\left(\mathrm{a}^{2}+\mathrm{b}^{2}\right)^{1 / 2}$ & Ramallo and Mascheroni (2012) \\
\hline Hue angle, ${ }^{\circ}$ & $\mathrm{h}^{\circ}=\tan ^{-1}\left(\frac{\mathrm{b}}{\mathrm{a}}\right)$ & Alemrajabi et al. (2012) \\
\hline Total color change, $\Delta \mathrm{E}$ & $\Delta \mathrm{E}=\sqrt{\left(\mathrm{L}-\mathrm{L}^{*}\right)^{2}+\left(\mathrm{a}-\mathrm{a}^{*}\right)^{2}+\left(\mathrm{b}-\mathrm{b}^{*}\right)^{2}}$ & Tan et al. (2001) \\
\hline
\end{tabular}

Table 2. Calculated color parameters 

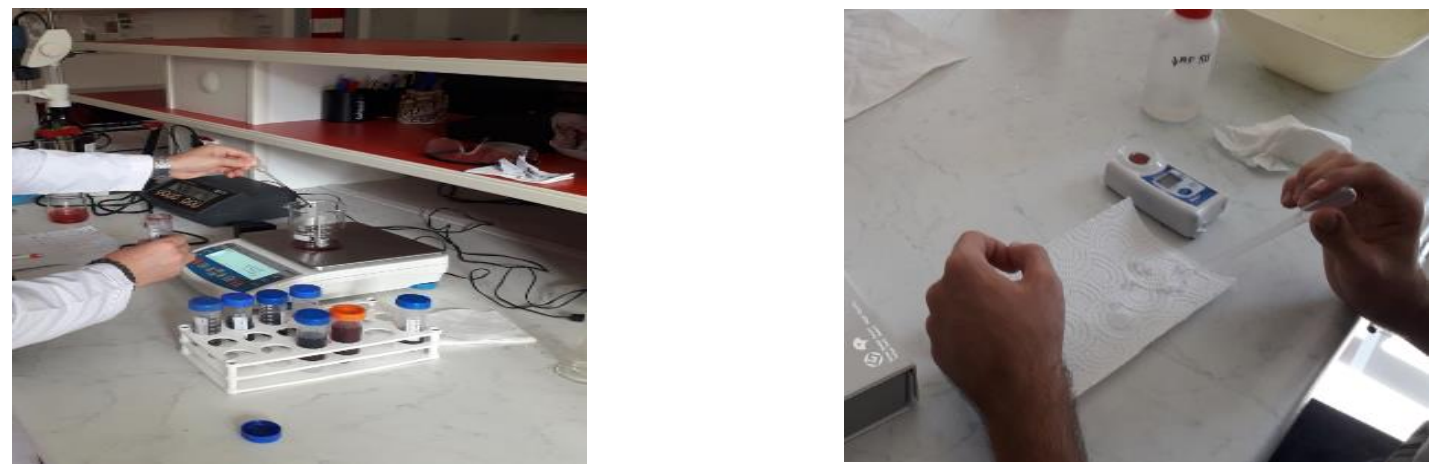

Figure 2. Phytochemical analyses of fresh and dried fruits

\section{Results and Discussion}

\section{Drying Performance}

Initial moisture contents of semi-ripe and full-ripe black mulberry samples were respectively measured as $86.74 \%$ and $82.95 \%$. Such values indicated that sugar-like water soluble substances increased, thus moisture contents decreased with the progress of ripening. Average length, width and thickness of semi-ripe fruits were respectively measured as $2.6 \mathrm{~cm}, 1.6 \mathrm{~cm}$ and $1.5 \mathrm{~cm}$ and the values of full-ripe fruits were respectively measured as $2.7 \mathrm{~cm}, 1.8$ $\mathrm{cm}$ and $1.6 \mathrm{~cm}$. Average drying durations and final moisture values of semi-ripe and full-ripe black mulberry samples are provided in Table 3.

As can be seen from Table 3, semi-ripe fruits had longer drying durations than the full-ripe fruits since semi-ripe fruits had greater initial moisture levels and water molecules are tighter bound to fruit tissue because these fruits did not complete ripening fully.

Tlatelpa-Becerro et al. (2020) investigated the effects of different drying temperatures and ripening levels on drying durations of green and ripened hawthorn fruits. Researchers reported wet-basis initial moisture content of green and ripened fruits respectively as $79.81 \%$ and $78.01 \%$ and indicated that green fruits had longer drying durations to reach the desired final moisture levels. Pirone et al. (2014) applied different pre-treatments to sweet cherry fruits at different ripening levels and investigated the effects of these pre-treatments on drying and quality parameters. Researchers classified ripening levels as green and ripened and reported shorter drying durations for ripened fruits than for the green fruits.

\section{Thin-Layer Drying Models}

Time-dependent drying ratios of semi-ripe and full-ripe fruits were determined throughout the drying duration and these values were incorporated into thin layer drying models. The mathematical models best estimating drying ratios were determined. Results for Page model are provided in Table 4.
As can be seen from Table 4, Page model best estimated drying ratios of semi-ripe and full-ripe fruits at $60^{\circ} \mathrm{C}$ drying temperature $\left(\mathrm{R}^{2}=0.9963\right)$. The results for Midilli-Küçük mathematical model are provided in Table 5. As can be seen from Table 5, Midlli-Küçük model best estimated drying ratios of semi-ripe fruits at $60^{\circ} \mathrm{C}$ drying temperature $\left(\mathrm{R}^{2}=0.9995\right)$. For full-ripe fruits, the best estimations were achieved at $70^{\circ} \mathrm{C}$ drying temperature $\left(\mathrm{R}^{2}=0.9994\right)$. The results for Yağcioğlu model are provided in Table 6 .

As can be seen from Table 6, Yağcıŏlu model best estimated drying ratios of semi-ripe fruits at $50^{\circ} \mathrm{C}$ drying temperature $\left(\mathrm{R}^{2}=0.9996\right)$. For the full-ripe fruits, the best estimations were achieved at 50 and $70^{\circ} \mathrm{C}$ drying temperatures $\left(\mathrm{R}^{2}=0.9984\right)$. Mathematical models that as best estimate drying curves of semi-ripe and full-ripe black mulberry fruits, respectively; was identified Yağcıoğlu$50^{\circ} \mathrm{C}$ and Midilli-Küçük-70 ${ }^{\circ} \mathrm{C}$.

\section{Effective Diffusion}

Effective diffusion and activation energy values of dried semi-ripe and full-ripe black mulberry fruits are provided in Table 7 .

Effective diffusion values of dried semi-ripe fruits varied between $9.140 \times 10^{-7}-3.830 \times 10^{-6} \mathrm{~m}^{2} . \mathrm{s}^{-1}$ and

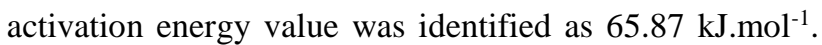
Effective diffusion values of full-ripe fruits varied between $1.449 \times 10^{-6}-6.773 \times 10^{-6} \mathrm{~m}^{2} . \mathrm{s}^{-1}$ and activation energy value was identified as $70.94 \mathrm{~kJ}^{\mathrm{mol}}{ }^{-1}$. Darvishi et al. (2014) investigated the effects of microwave power on effective diffusion values of microwave-dried white mulberry fruits and reported that effective diffusion values increased with increasing microwave powers and the values varied between $1.06 \times 10^{-8}-3.45 \times 10^{-8} \mathrm{~m}^{2} . \mathrm{s}^{-1}$. Activation energy was identified as $14.19 \mathrm{~W} \cdot \mathrm{g}^{-1}$. Doymaz and Kıpçak (2019) dried mulberry fruit in an infrared drier at 50, 62, 74, 88 and $104 \mathrm{~W}$ powers and reported that effective diffusion values increased with increasing powers and the values varied between $1.14 \times 10^{-9}-3.08 \times 10^{-9} \mathrm{~m}^{2} . \mathrm{s}^{-1}$.

Table 3. Average drying durations and final moisture values of the samples

\begin{tabular}{c|ccc}
\hline Material & Temperature $\left({ }^{\circ} \mathrm{C}\right)$ & Final moisture (wet-basis) & Drying duration (hour) \\
\hline \multirow{3}{*}{ Semi-ripe } & 50 & 11.47 & 92 \\
& 60 & 11.99 & 48 \\
\hline \multirow{3}{*}{ Full-ripe } & 70 & 11.79 & 22 \\
& 50 & 10.38 & 77 \\
& 60 & 10.35 & 42 \\
\hline
\end{tabular}


Table 4. Results for Page model

\begin{tabular}{c|ccccc}
\hline Material & Temperature $\left({ }^{\circ} \mathrm{C}\right)$ & $\mathrm{k}$ & $\mathrm{h}$ & $\mathrm{R}^{2}$ & $\mathrm{P}$ \\
\hline \multirow{3}{*}{ Semi-ripe } & 50 & 0.0125 & 1.1923 & 0.9940 & $\mathrm{P}<0.0001$ \\
& 60 & 0.0590 & 1.0190 & 0.9963 & $\mathrm{P}<0.0001$ \\
& 70 & 0.0866 & 1.1369 & 0.9952 & $\mathrm{P}<0.0001$ \\
\hline \multirow{3}{*}{ Full-ripe } & 50 & 0.0108 & 1.2785 & 0.9901 & $\mathrm{P}<0.0001$ \\
& 60 & 0.0356 & 1.2118 & 0.9963 & $\mathrm{P}<0.0001$ \\
& 70 & 0.0541 & 1.4102 & 0.9960 & $\mathrm{P}<0.0001$ \\
\hline
\end{tabular}

Table 5. Results for Midilli-Küçük model

\begin{tabular}{|c|c|c|c|c|c|c|c|}
\hline Material & Temperature $\left({ }^{\circ} \mathrm{C}\right)$ & $\mathrm{k}$ & $\mathrm{h}$ & $\mathrm{j}$ & $\mathrm{m}$ & $\mathrm{R}^{2}$ & $\mathrm{P}$ \\
\hline \multirow{3}{*}{ Semi-ripe } & 50 & 1.0267 & 0.9827 & 0.0180 & -0.0015 & 0.9995 & $\mathrm{P}<0.0001$ \\
\hline & 60 & 0.9427 & 0.9827 & 0.0645 & -0.0014 & 0.9990 & $\begin{array}{l}\mathrm{P}<0.0001 \\
\mathrm{P}<0.0001 \\
\mathrm{P}<0.0001 \\
\mathrm{P}=0.0002\end{array}$ \\
\hline & 70 & 0.9960 & 0.9957 & 0.0991 & -0.0048 & 0.9988 & $\begin{array}{l}\mathrm{P}<0.0001 \\
\mathrm{P}<0.0001 \\
\mathrm{P}<0.0001 \\
\mathrm{P}=0.0069\end{array}$ \\
\hline \multirow{3}{*}{ Full-ripe } & 50 & 1.1717 & 0.9635 & 0.0120 & -0.0018 & 0.9986 & $\mathrm{P}<0.0001$ \\
\hline & 60 & 1.1760 & 0.9734 & 0.0348 & -0.0012 & 0.9990 & $\begin{array}{l}\mathrm{P}<0.0001 \\
\mathrm{P}<0.0001 \\
\mathrm{P}<0.0001 \\
\mathrm{P}=0.0020\end{array}$ \\
\hline & 70 & 1.2924 & 0.9895 & 0.0577 & -0.0056 & 0.9994 & $\begin{array}{l}\mathrm{P}<0.0001 \\
\mathrm{P}<0.0001 \\
\mathrm{P}<0.0001 \\
\mathrm{P}=0.0084\end{array}$ \\
\hline
\end{tabular}

Table 6. Results for Yağcioğlu model

\begin{tabular}{c|lccccc}
\hline Material & Temperature $\left({ }^{\circ} \mathrm{C}\right)$ & $\mathrm{k}$ & $\mathrm{h}$ & $\mathrm{h}$ & $\mathrm{R}^{2}$ & $\mathrm{P}$ \\
\hline & 50 & $\mathrm{k}: 1.2444$ & 0.0165 & -0.2598 & 0.9996 & $\mathrm{P}<0.0001$ \\
Semi-ripe & 60 & $\mathrm{k}: 1.0304$ & 0.0523 & -0.0609 & 0.9989 & $\mathrm{P}<0.0001$ \\
& 70 & $\mathrm{k}: 1.1472$ & 0.0874 & -0.1542 & 0.9989 & $\mathrm{P}<0.0001$ \\
& & & & & $\mathrm{P}=0.0002$ \\
\hline & 50 & $\mathrm{k}: 1.4093$ & 0.0157 & -0.4264 & 0.9984 & $\mathrm{P}<0.0001$ \\
Full-ripe & 60 & $\mathrm{k}: 1.1483$ & 0.0487 & -0.1486 & 0.9984 & $\mathrm{P}<0.0001$ \\
& 70 & $\mathrm{k}: 1.4807$ & 0.0692 & -0.4606 & 0.9974 & $\mathrm{P}<0.0001$ \\
& & & & & & $\mathrm{P}<0.0001$ \\
& & & & & & $\mathrm{P}=0.0042$ \\
\hline
\end{tabular}

Table 7. Effective diffusion and activation energy values

\begin{tabular}{l|ccc}
\hline Material & Temperature $\left({ }^{\circ} \mathrm{C}\right)$ & Effective diffusion $\left(\mathrm{m}^{2} . \mathrm{s}^{-1}\right)$ & Activation energy $\left(\mathrm{kJ} . \mathrm{mol}^{-1}\right)$ \\
\hline \multirow{3}{*}{ Semi-ripe } & 50 & $9.140 \times 10^{-7}$ & 65.87 \\
& 60 & $1.685 \times 10^{-6}$ & \\
\hline \multirow{3}{*}{ Full-ripe } & 70 & $3.830 \times 10^{-6}$ & 70.94 \\
& 50 & $1.449 \times 10^{-6}$ & \\
\hline
\end{tabular}

Table 8. Specific energy consumptions

\begin{tabular}{l|cc}
\hline Material & Temperature $\left({ }^{\circ} \mathrm{C}\right)$ & Specific energy consumption $\left(\mathrm{kWh} . \mathrm{kg}\right.$ water $\left.{ }^{-1}\right)$ \\
\hline \multirow{3}{*}{ Semi-ripe } & 50 & 106.14 \\
& 60 & 141.45 \\
& 70 & 95.31 \\
\hline \multirow{3}{*}{ Full-ripe } & 50 & 126.15 \\
& 60 & 177.27 \\
\hline
\end{tabular}


Activation energy was reported as $2.015 \mathrm{~kW} . \mathrm{kg}^{-1}$. Kıpçak and Doymaz (2020) conducted a mulberry drying study with microwave oven at 90,180 and $360 \mathrm{~W}$ powers and reported effective diffusion values as between $4.79 \times 10^{-8}-2.60 \times 10^{-7} \mathrm{~m}^{2} \cdot \mathrm{s}^{-1}$. Activation energy was identified as $13.15 \mathrm{~kW} \cdot \mathrm{kg}^{-1}$

\section{Specific Energy Consumption}

Specific energy consumption values of dried semi-ripe and full-ripe black mulberry fruits at different drying temperatures are provided in Table 8.

Specific energy consumptions varied between 95.31$141.45 \mathrm{kWh} . \mathrm{kg}^{-1}$ water for semi-ripe fruits and between 95.93-177.27 kWh. $\mathrm{kg}^{-1}$ water for full-ripe fruits. Golpour et al. (2020) conducted a white mulberry infrared drying study at 40,55 and $70^{\circ} \mathrm{C}$ temperatures, 500, 1000 and 1500 $\mathrm{W}$ infrared powers and $0.4,1$ and $1.6 \mathrm{~m} . \mathrm{s}^{-1}$ air velocities and used artificial neural networks for optimization of drying parameters. Researchers reported the specific energy consumption of the best method $\left(70^{\circ} \mathrm{C}\right.$ temperature, 1464.57 W infrared power and $0.4 \mathrm{~m} . \mathrm{s}^{-1}$ air velocity) as 166.55 MJ.kg-1 (46.27 kWh. kg-1). Rad et al. (2018) determined specific energy consumptions of white mulberry drying operations under hot air and infrared drying conditions. The greatest specific energy

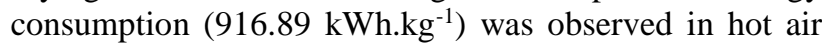
drier and the lowest value $\left(113.92 \mathrm{kWh} \mathrm{kg}^{-1}\right)$ was observed in infrared drier. Taghinezhad et al. (2020) dried blackberry fruits in a hybrid drier (hot air infrared drier) and reported the greatest and the lowest specific energy consumptions as $239.91 \mathrm{kWh} . \mathrm{kg}^{-1}$ and $70.57 \mathrm{kWh} . \mathrm{kg}^{-1}$, respectively.

\section{Color Parameters}

Measured and calculated color parameters of semi-ripe black mulberry fruits under different drying conditions are provided in Table 9.

Effects of drying methods on color parameters of semiripe black mulberry fruits were found to be significant $(\mathrm{P}<0.05)$ (Table 9). In terms of brightness $\left(L^{*}\right)$, the closest values to fresh semi-ripe fruits were observed at 50 and $60^{\circ} \mathrm{C}$ drying temperatures. In terms of the other color parameters, as compared to fresh fruits, there were not any significant similarities. Therefore, semi-ripe black mulberry fruits are recommended to be dried at 50 or $60^{\circ} \mathrm{C}$ drying temperatures for better preservation of color parameters. Measured and calculated color parameters of full-ripe black mulberry fruits under different drying conditions are provided in Table 10.

Effects of drying methods on color parameters of fullripe black mulberry fruits were found to be significant $(\mathrm{P}<0.05)$ (Table 10). As compared to color values of fresh fruits, the closest blueness $\left(b^{*}\right)$ value was observed at 50 $50^{\circ} \mathrm{C}$ drying temperature and the closest Hue angle value was observed again at $50^{\circ} \mathrm{C}$ drying temperature. Therefore, full-ripe black mulberry fruits are recommended to be dried at $50^{\circ} \mathrm{C}$ drying temperatures for better preservation of color parameters. When the results provided in Table 9 and Table 10 were assessed together, drying methods, drying temperatures and ripening levels significantly influenced final color values of dried mulberry fruits. Özkan and Karabacak (2019) dried white mulberry sheets in hot-air drier at 50 and $60^{\circ} \mathrm{C}$ temperatures and reported significant differences in $L^{*}, a^{*}, b^{*}, C^{*}$ and hue values of dried products and fresh products $(\mathrm{P}<0.05)$ and indicated that color parameters could not be preserved. Boz et al. (2016) reported L values of dried white mulberry fruits as between 31.64-35.86, on the other hand, present values varied between $27.78-30.36$.

Chemical analysis results for semi-ripe black mulberry fruits dried under different temperatures are provided in Table 11 .

Effects of drying methods on $\mathrm{pH}$, TA and WSDM of semi-ripe fruits were found to be significant $(\mathrm{P}<0.05)$ (Table 11). As compared to fresh fruits, the closest $\mathrm{pH}$ value was observed at $50^{\circ} \mathrm{C}$ drying temperature. In terms of titratable acidity, different drying temperatures did not yield significant differences. The closest WSDM values to fresh fruits were observed at $70^{\circ} \mathrm{C}$ drying temperature. Chemical analysis results for full-ripe back mulberry fruits dried under different temperatures are provided in Table 12.

Effects of drying methods on $\mathrm{pH}$, TA and WSDM of full-ripe fruits were found to be significant $(\mathrm{P}<0.05)$ (Table 12). As compared to fresh fruits, the closest $\mathrm{pH}$ value was observed at $60^{\circ} \mathrm{C}$ drying temperature. Drying temperature of $70^{\circ} \mathrm{C}$ was found to be more suitable for titratable acidity and $50^{\circ} \mathrm{C}$ for WSDM. There are previous studies about the effects of drying methods on quality traits of white mulberry fruits. Ojha et al. (2017) conducted an osmo-air drying study and reported increased $\mathrm{pH}$ values of white mulberry fruits. Ercişli and Orhan (2007) reported pH values of dried white mulberries as between 3.52-5.60.

Table 9. Color parameters of semi-ripe fruits

\begin{tabular}{l|ccccccc}
\hline Drying method & Temperature $\left({ }^{\circ} \mathrm{C}\right)$ & $L^{*}$ & $a^{*}$ & $b^{*}$ & $\mathrm{C}$ & Hue $^{\circ}$ & $\Delta \mathrm{E}$ \\
\hline Fresh & - & $35.41^{\mathrm{b}}$ & $25.73^{\mathrm{a}}$ & $14.90^{\mathrm{a}}$ & $29.94^{\mathrm{a}}$ & $30.17^{\mathrm{a}}$ & - \\
\hline \multirow{3}{*}{ Oven } & 50 & $36.97^{\mathrm{ab}}$ & $12.39^{\mathrm{b}}$ & $4.29^{\mathrm{b}}$ & $13.28^{\mathrm{b}}$ & $17.02^{\mathrm{b}}$ & $27.11^{\mathrm{a}}$ \\
& 60 & $38.64^{\mathrm{a}}$ & $13.88^{\mathrm{b}}$ & $4.97^{\mathrm{b}}$ & $14.79^{\mathrm{b}}$ & $19.67^{\mathrm{b}}$ & $27.94^{\mathrm{a}}$ \\
& 70 & $37.58^{\mathrm{ab}}$ & $14.55^{\mathrm{b}}$ & $5.80^{\mathrm{b}}$ & $15.72^{\mathrm{b}}$ & $21.95^{\mathrm{b}}$ & $26.88^{\mathrm{a}}$ \\
\hline
\end{tabular}

Table 10. Color parameters of semi-ripe fruits

\begin{tabular}{l|ccccccc}
\hline Drying method & Temperature $\left({ }^{\circ} \mathrm{C}\right)$ & $L^{*}$ & $a^{*}$ & $b^{*}$ & $\mathrm{C}$ & $\mathrm{Hue}^{\mathrm{o}}$ & $\Delta \mathrm{E}$ \\
\hline Fresh & - & $16.44^{\mathrm{c}}$ & $11.43^{\mathrm{a}}$ & $-0.80^{\mathrm{a}}$ & $11.49^{\mathrm{a}}$ & $-4.73^{\mathrm{a}}$ & - \\
\hline \multirow{3}{*}{ Oven } & 50 & $31.41^{\mathrm{a}}$ & $8.18^{\mathrm{b}}$ & $-0.50^{\mathrm{a}}$ & $8.23^{\mathrm{b}}$ & $-4.24^{\mathrm{a}}$ & $24.70^{\mathrm{a}}$ \\
& 60 & $25.64^{\mathrm{b}}$ & $5.83^{\mathrm{c}}$ & $-1.76^{\mathrm{b}}$ & $6.13^{\mathrm{c}}$ & $-17.13^{\mathrm{b}}$ & $20.60^{\mathrm{b}}$ \\
& 70 & $30.65^{\mathrm{a}}$ & $5.63^{\mathrm{c}}$ & $-1.97^{\mathrm{b}}$ & $5.99^{\mathrm{c}}$ & $-19.34^{\mathrm{b}}$ & $25.45^{\mathrm{a}}$ \\
\hline
\end{tabular}


Table 11. Chemical analysis results for semi-ripe black mulberry fruits

\begin{tabular}{l|cccc}
\hline Drying method & Temperature $\left({ }^{\circ} \mathrm{C}\right)$ & $\mathrm{pH}$ & TA & WSDM \\
\hline Fresh & - & $3.16^{\mathrm{a}}$ & $7.50^{\mathrm{b}}$ & $1.73^{\mathrm{d}}$ \\
\hline \multirow{3}{*}{ Oven } & 50 & $2.99^{\mathrm{b}}$ & $15.47^{\mathrm{a}}$ & $4.10^{\mathrm{a}}$ \\
& 60 & $2.83^{\mathrm{c}}$ & $14.45^{\mathrm{a}}$ & $3.67^{\mathrm{b}}$ \\
& 70 & $2.87^{\mathrm{c}}$ & $14.69^{\mathrm{a}}$ & $3.30^{\mathrm{c}}$ \\
\hline
\end{tabular}

Table 12. Chemical analysis results for full-ripe black mulberry fruits

\begin{tabular}{l|cccc}
\hline Drying method & Temperature $\left({ }^{\circ} \mathrm{C}\right)$ & $\mathrm{pH}$ & TA & SÇKM \\
\hline Fresh & - & $3.45^{\mathrm{ab}}$ & $3.38^{\mathrm{d}}$ & $3.10^{\mathrm{c}}$ \\
\hline Oven & 50 & $3.39^{\mathrm{c}}$ & $6.98^{\mathrm{a}}$ & $5.23^{\mathrm{b}}$ \\
& 60 & $3.45^{\mathrm{ab}}$ & $6.10^{\mathrm{b}}$ & $5.87^{\mathrm{a}}$ \\
& 70 & $3.50^{\mathrm{a}}$ & $5.42^{\mathrm{c}}$ & $5.60^{\mathrm{ab}}$ \\
\hline
\end{tabular}

\section{Conclusion}

Present findings revealed that drying air temperatures and ripening levels had significant effects on drying performance, drying model, specific energy consumption, effective diffusion, activation energy, color and chemical characteristics of black mulberry fruits $(\mathrm{P}<0.05)$ Significant decreases were observed with increasing drying temperatures. The shortest drying duration and the greatest specific energy consumptions were observed in full-ripe fruits. Effective diffusion and activation energy values of full-ripe fruits were greater than the values of semi-ripe fruits. In terms of color parameters, semi-ripe fruits are recommended to be dried at 50 or $60^{\circ} \mathrm{C}$ drying temperatures and full-ripe fruits should be dried at $50^{\circ} \mathrm{C}$ drying temperature for better preservation of color parameters. On the other hand, a common proper drying temperature could not be identified for acidity $(\mathrm{pH})$, water soluble dry matter and titratable acidity.

\section{Acknowledgement}

This study was produced from Muhammed Taşova's $\mathrm{PhD}$ thesis and was supported by Scientific Research Projects Department of Tokat Gaziosmanpaşa University (project number: 2019/45).

\section{References}

Alemrajabi AA, Rezaee F, Mirhosseini M, Esehaghbeygi A. 2012. Comparative evaluation of the effects of electrohydrodynamic, oven, and ambient air on carrot cylindrical slices during drying proces. Drying Technology, 30: 88-96. doi: 10.1080/07373937.2011.608913.

Boz H, Karaoğlu MM, Kaban G. 2016. The effects of cooking time and sugar on total phenols, hydroxymethylfurfural and acrylamide content of mulberry leather (pestil). Quality Assurance and Safety of Crops and Foods, 8(4): 493-500.

Cemeroğlu B. 1992. Meyve ve Sebze İşleme Endüstrisinde Temel Analiz Metodları. Biltav Yayıncılık, syf: 381. Ankara.

Chen Q, Li Z, Bi J, Zhou L, Yi J, Wu X. 2017. Effect of hybrid drying methods on physicochemical, nutritional and antioxidant properties of dried black mulberry. LWT-Food Science And Technology, 80: 178-184.

Crank J. 1979. The mathematics of diffusion". Oxford University press, London.

Darvishi H, Zarein M, Minaei S, Khafajeh H. 2014. Exergy and energy analysis, drying kinetics and mathematical modeling of white mulberry drying process. International Journal of Food Engineering, 10(2): 269-280.
Dobooğlu H. 2012. Liyofilizasyonun Karadut (Morus nigra) Kurutmadaki Potansiyelinin Konveksiyonel Ve Vakumlu Kurutma Teknikleriyle Kiyaslanarak Belirlenmesi, Yüksek Lisans Tezi, Kahramanmaraş Sütçü İmam Üniversitesi, Gıda Mühendisliği Bölümü, Kahramanmaraş.

Doymaz I, Kıpcak AS. 2019. Dryıng characterıstics investıgation of black mulberry dried via infrared method. Journal of Thermal Engineering, 5(2): 13-21.

Doymaz, İ., Tuğrul, N. ve M. Pala., 2003. Maydanozun Kuruma Karakteristiklerinin İncelenmesi. Yıldız Teknik Üniversitesi Dergisi, (3), 1-8.

Doymaz I. 2011. Thin-layer drying characteristics of sweet potato slices and mathematical modelling. Heat Mass Transfer; 47: 277-85.

Ercisli S, Orhan E. 2007. Chemical composition of white (Morus alba), red (Morus rubra) and black (Morus nigra) mulberry fruits. Food Chemistry, 103(1): 1380-1384.

Ergüneş G, Güneş M, Çekiç Ç. 2003. Dut meyvesinde değişik kurutma tekniklerinin kuru ürün kalitesine etkisi. Ulusal Kivi ve Üzümsü Meyveler Sepozyumu, Ordu, 442- 447.

Figiel A. 2010. Drying kinetics and quality of beetroots dehydrated by combination of convective and vacuummicrowave methods. Journal of Food Engineering, 98 (4): 461-470.

Ghanbarian D, Torku-Harchegani M, Sadeghi M, Pirbalouti AG. 2019. Ultrasonically improved convective drying of peppermint leaves: Influence on the process time and energetic indices. Renewable Energy, https://doi.org/10.1016/j.renene.2019.10.024.

Golpour I, Kaveh M, Chayjan RA, Guiné RPF. 2020. Optimization of infrared-convective drying of white mulberry fruit using response surface methodology and development of a predictive model through artificial neural network. International Journal of Fruit Science, doi.org/10.1080/15538362.2020.1774474.

Karaçalı İ. 1990. Bahçe Ürünlerinin Muhafazası ve Pazarlanması, syf: 413 Bornova- ̇̇zmir.

McGuire RG. 1992. Reporting of objective color measurements. HortScience, 27, 1254 - 1255.

Midilli A, Kucuk H, Yapar Z. 2002. A new model for single layer drying. Drying Technology, 20(7): 1503-1513.

Ojha P, Sigdel A, Karki R, Mishra A, Subedi U, Karki TB. 2017. Physiochemical and bioactive characteristic of osmo-air dried mulberry fruit. Nepalese Horticulture, 12(1).

Özgen F. 2014. Design of a convective type drying system for apple drying process. Mühendis ve Makine, 55(656): 42-49.

Page G. 1949. Factors Influencing the Maximum Rates of AirDrying Shelled Corn in Thin Layer. M.S. Thesis. Department of Mechanical Engineering, Purdue University, West Lafayette, IN, USA. 
Panagopoulou EA, Chiou A, Nikolidaki EK, Christea M, Karathanos VT. 2019. Corinthian raisins (Vitis vinifera L. var. Apyrena) antioxidant and sugar contentas affected by the drying process: a 3-year study. Journal Sci Food Agric, 99: 915-922.

Pirone BN, Michelis AD, Salvatori DM. 2014. Pretreatments effect in drying behaviour and colour of mature and immature 'napolitana' sweet cherries. Food and Bioprocess Technology, 7(1): 1640-1655.

Pixton SW, Warburton S. 1973. Determination of moisture content and equilibrium relative humidity of dried fruitSultanas. Journal of Stored Products Research, 8(4): 263-270.

Polatc1 H, Tarhan S. 2009. The Effects of various drying methods on the drying time and quality of basil (Ocimum Basilicum)*. Gaziosmanpaşa Üniversitesi Ziraat Fakültesi Dergisi, 26(1): 61-70.

Polatci H, Taşova M, Saraçoğlu O, Taşkın O. 2018. Determination of drying parameters of peach (Prunus persica L.) pomace at different temperatures. Tarım Makinaları Bilimi Dergisi, 14(3): 149-156.

Rad SJ, Kaveh M, Sharabiani VR, Taghihezhad E. 2018. Fuzzy logic, artificial neural network and mathematical model for prediction of white mulberry drying kinetics. Heat and Mass Transfer, 54(1): 3361-3374, doi.org/10.1007/s00231-018$2377-4$.

Ramallo LA, Mascheroni RH. 2012. Quality evoluation of pineapple fruit during drying process. Food and B1oproducts Processing, 99: 275-283.
Suna S, Özkan-Karabacak A. 2019. Investigation of drying kinetics and physicochemical properties of mulberry leather (pestil) dried with different methods. Journal of Food Processing and Preservation, 43(8): 1-9.

Taghinezhad E, Kaveh M, Khalife E, Chen G. 2020. Drying of organic blackberry in combined hot air-infrared dryer with ultrasound pretreatment. Drying Techonology, doi.org/10.1080/07373937.2020.1753066.

Tlatelpa-Becerro A, Rico-Martínez R, Urquiza G, CalderónRamírez M. 2020. Obtaining of Crataegus mexicanaleaflets using an indirect solar dryer. Ingeniería de alimentos Revista Mexicana deIngeniería Química, 19(2): 669-676.

Tan M, Chua KJ, Mujumdar AS, Chou SK. 2001. Effect of osmotic pre-treatment and infrared radiation of drying rate and color changes during drying of potato and pineapple. Drying Technol, 19(9): 2193-2207.

Tellez MC, Tellez BC, Navarro JAA, Sierra JCO, Perez GAM. 2019. Kinetics of Drying Medicinal Plants by Hybridization of Solar Technologies. Cahapter Drying Unit Operations, 117.

Türker İ, İşleroğlui H. 2017. Kinetics of anthocyanins, phenolic compounds and antioxidant capacity changes of mahaleb puree in infrared drying process. G1da Dergisi, 42(4): 422430.

Wojdylo A, Figiel A, Lech K, Nowicka P, Oszmianski J. 2014. Effect of convective and vacuum-microwave drying on the bioactive compounds, color, and antioxidant capacity of sour cherries. Journal of Food Bioprocess Technologies, 7: 829841.

Yağcıoglu A. 1999. Tarımsal Ürünleri Kurutma Tekniği. Ege Üniversitesi Ziraat Fakültesi yayınları No: 536. Bornova, İzmir. 